\title{
Multiplemedia Instruction and Learning Style: Their Effects on Achievement of High School Chemistry Students
}

\author{
VICTORIA O. SUMANPAN \\ vos1223@yahoo.com \\ Mindanao University of Science \& Technology
}

Date Submitted: November 9. 2007

Final Revision Accepted: February 15, 2008

\begin{abstract}
The study determined the effectiveness of multiplemedia instruction compared to lecture-discussion on the achievement scores of high school chemistry students when grouped according to learning styles. The researcher used the Index of Learning Styles and The Teacher Made Chemistry Test. The subjects of the study were the students of the Secondary Laboratory School (SLS) of Mindanao Polytechnic State College (MPSC), Lapasan, Cagayan de Oro City. The study utilized two research designs, namely; the pretest-posttest quasi-experimental design and the descriptive design. The stastical techniquics used were the Three Way Analysis of Covariance, mean, frequency, standard deviation, and F-statistics. The findings of the study showed that there is no significant difference in the achievement scores of the students exposed to lecture-discussion method and multiplemedia instruction even when grouped according to their learning styles. Student achievement of both groups increased as gleaned from the pretest and post test results.
\end{abstract}

Key words - Multiplemedia instruction, Felder-Silverman learning styles model, chemistry achievement scores.

\section{INTRODUCTION}

Multiple Media in Chemistry teaching is an instructional technology that is now utilized in the classroom in other countries as well as in the Philippines. Video tapes, computer simulations, virtual laboratories, animated science trials, experiment toolkits and multimedia software can encourage students to think like scientists as science education begins to shift away from merely learning about science to doing science, educators need tools at their disposal that can help students make that shift (Brungardt \& Zollman 1996).

This kind of instructional technology stimulates students to learn and to like 
science and thereby minimize the student's dislike in chemistry due to the difficulty in visualizing chemical phenomena and processes (Harwood \& Mc Mahon 1997). While multimedia encourages students' to learn Chemistry, learning styles would assist the educators to assess students' way of perceiving things in their learning style profile (Kozma \& Russell 2005). Litzenger \& Osif (1992) described learning styles as the different ways in which children and adults think and learn. They see that each of us develops a preferred and consistent set of behaviors or approaches to learning.

In order to understand the learning process, they break it into several processes: cognition, e.g. how one acquires knowledge; conceptualization, e.g. how one processes information; and effective e.g. people's motivation, decision-making styles, and emotional preferences. The Felder-Silverman Learning Style Model is utilized in this study. This model has four learning styles such as: active and reflective learners, sensing or intuitive learners, visual or verbal learners and sequential and global learners.

\section{FRAMEWORK}

The study was anchored on two theories: Constructivism theory and Learning style theory. The theory of Constructivism suggests an approach to teaching that gives the learner the opportunity for concrete, contextually meaningful experience through which they can search for patterns, raise their own question and construct their own model and concepts. In this model of teaching, the classroom is seen as a community of learners engaged in activity, discourse and reflection. The student's interaction with multimedia in the classroom gives them the concrete and hands-on experience in learning, according to (Lowe 2005) people remember only $10 \%$ of the knowledge they hear and only $15 \%$ of the knowledge they see. It is estimated that $35 \%$ of the knowledge they received simultaneously by audio and visual learning method is remembered. Teaching methods vary as well as learning style preferences. According to (Kind 2000), just as there is a striking difference in the way people learn and process information, there are significant differences in how learning styles are defined and measured.

\section{OBJECTIVES OF THE STUDY}

The research sought answers to the following objectives: (1) to compare the achievement scores of the students taught using multiplemedia instruction with those taught using the lecture discussion method when grouped by learning styles: sensing or intuitive; visual or verbal; active or reflective; and, global or sequential.

\section{METHODOLOGY}

The study employed the pretest-posttest quasi-experimental research design and descriptive research design. There are two treatments: Multimedia Instruction and the lecture-discussion. The comparison group was subjected to the lecture discussion method, while the experimental group was exposed to Multimedia Instruction. Both groups were given the pretest and posttest of the achievement test and the learning styles. The setting of this study was the Secondary Laboratory School (SLS) of the Mindanao Polytechnic State College (MPSC). This is located at Claro M. Recto Avenue, Lapasan, Cagayan de Oro City, Region X. There were three sections in the third year high school of Mindanao Polytechnic State College (MPSC). Out of the three sections two sections were randomly selected, one was the comparison group and the other 
was the experimental group. The experimental group was composed of forty-eight (48) students while the comparison group consisted of 50 students. The researcher used the index of learning styles questionnaire which was taken from http:www.ncu. edu/felder-public/ILSpage.html. Richard M. Felder created the Index of Learning Styles in 1991, a chemical engineering professor at North Carolina State University, and Barbara A. Soloman, then the coordinator of advising for the N.C. State University First-Year College. The teacher-made chemistry achievement test, consisted of topics on Periodicity of Elements and Nature of Chemical Bonds. It was administered as pretest and posttest to evaluate the student's achievement across the four areas of the cognitive domain namely: knowledge, comprehension, analysis and application.

\section{RESULTS AND DISCUSSION}

Application of the three-way Analysis of Covariance in table 4.1 revealed that the experimental group and comparison group did not differ significantly on their achievement scores since the corresponding probabilities (0.381) associated with the F-statistic is greater than $\alpha=0.05$, which led to the acceptance of the null hypothesis. In terms of their learning styles (Ref/Act) learners in the pretest andposttest, the students achievement scores did not exhibit significant differences since their associated probabilities $(0.113 \& 0.683)$, are greater than $\alpha=0.05$. This led to the acceptance of the null hypothesis. This means that the students who are exposed to lecture discussion method performed better than the students taught in multimedia instruction. It further implies that the multimedia instruction has less effect in constructing and understanding new concepts and knowledge in Chemistry, which was prompted by the constructivists. This result can be attributed to the type of CD used, which was prepared by the teacher herself.

Table 4.1 Results of the analysis of covariance on reflective/active (RA) learners

\begin{tabular}{|c|c|c|c|c|c|}
\hline $\begin{array}{l}\text { Source of } \\
\text { Variation }\end{array}$ & Sum of Squares & $\mathrm{df}$ & Mean Square & $\mathrm{F}$ & Probability \\
\hline $\begin{array}{l}\text { Corrected } \\
\text { Model ( Bet.) }\end{array}$ & 1333.9599 & 22 & 60.635 & 1.798 & 0.033 \\
\hline Intercept & 2021.1391 & 20 & 21.139 & 59.923 & 0.000 \\
\hline Pretest & 340.430 & 13 & 40.430 & 10.093 & 0.002 \\
\hline Group & 26.234 & 1 & 26.234 & 0.778 & 0.381 \\
\hline $\begin{array}{l}\text { Learning Style } \\
\text { (Pre) }\end{array}$ & 208.381 & 3 & 69.460 & 2.059 & 0.113 \\
\hline $\begin{array}{l}\text { Learning Style } \\
\text { (Post) }\end{array}$ & 77.260 & 4 & 19.315 & 0.573 & 0.683 \\
\hline $\begin{array}{lr}\text { Group } & \& \\
\text { Learning } & \text { Style } \\
\text { (Pretest) } & \end{array}$ & 32.710 & 2 & 16.355 & 0.485 & 0.618 \\
\hline $\begin{array}{lr}\text { Group } & \& \\
\text { Learning } & \text { Style }\end{array}$ & 17.245 & 2 & 8.623 & 0.256 & 0.775 \\
\hline $\begin{array}{ll}\text { (Posttest) } & \\
\text { Learning } & \text { Style } \\
\text { (pre \& } & \text { post) }\end{array}$ & 66.535 & 5 & 13.30 & 0.395 & 0.851 \\
\hline $\begin{array}{lr}\text { Group } & \& \\
\text { Learning } & \text { Style } \\
\text { (Pre \& Posttest) }\end{array}$ & 42.895 & 3 & 14.298 & 0.424 & 0.73 \\
\hline Within Error & 245.958 & 74 & 33.729 & & \\
\hline Corrected Total & 3829.918 & 96 & & & \\
\hline
\end{tabular}


Table 4.2 Results of the analysis of covariance on visual/verbal learners

\begin{tabular}{|c|c|c|c|c|c|}
\hline Source of Variation & Sum of Squares & $\mathrm{df}$ & Mean Square & $\mathrm{F}$ & Probability \\
\hline $\begin{array}{l}\text { Corrected } \\
\text { (Bet) }\end{array}$ & 1563.991 & 21 & 74.476 & 24.65 & 0.002 \\
\hline Intercept & 1550.914 & 1 & 1550.914 & 51.334 & 0.000 \\
\hline Pretest & 485.071 & 1 & 485.071 & 16.055 & 0.000 \\
\hline Group & 86.599 & 1 & 86.599 & 2.866 & 0.095 \\
\hline $\begin{array}{l}\text { Learning } \\
\text { (Pre) }\end{array}$ & 194.671 & 3 & 64.890 & 2.148 & 0.101 \\
\hline $\begin{array}{l}\text { Learning Style } \\
\text { (Post) }\end{array}$ & 100.464 & 4 & 25.116 & 0.831 & 0.509 \\
\hline $\begin{array}{l}\text { Group \& Learning } \\
\text { Style (Pretest) }\end{array}$ & 145.513 & 3 & 48.504 & 1.605 & 0.915 \\
\hline $\begin{array}{l}\text { Group \& Learning } \\
\text { Style (Posttest) }\end{array}$ & 18.172 & 2 & 9.086 & 0.301 & 0.741 \\
\hline $\begin{array}{l}\text { Learning Style (pre } \\
\& \text { post) }\end{array}$ & 33.874 & 4 & 9.718 & 0.322 & 0.863 \\
\hline $\begin{array}{l}\text { Group \& Learning } \\
\text { Style (Pre \& } \\
\text { Posttest) }\end{array}$ & 125.825 & 2 & 62.912 & 2.082 & 0.132 \\
\hline Within Error & 2265.927 & 75 & 30.212 & & \\
\hline Corrected Total & 3829.918 & 96 & & & \\
\hline
\end{tabular}

The experimental and control groups did not differ significantly on their achievement scores since the corresponding probabilities (0.095) associated with the F-statistic is greater than $\alpha=0.05$ which led to the acceptance of the null hypothesis. In terms of their pretest and posttest of the Visual/Verbal learners, the students' achievement scores did not exhibit significant differences since their associated probabilities $(0.101 \&$ $0.509)$, are greater than $\alpha=0.05$. This led to the acceptance of the null hypothesis.

Table 4.3 Results of the analysis of covariance on sensitive/intuitive learners

\begin{tabular}{|c|c|c|c|c|c|}
\hline $\begin{array}{l}\text { Source of } \\
\text { Variation }\end{array}$ & Sum of Squares & $\mathrm{df}$ & Mean Square & $\mathrm{F}$ & Probability \\
\hline $\begin{array}{l}\text { Corrected } \\
\text { Model ( Bet.) }\end{array}$ & 1419.905 & 20 & 70.995 & 2.239 & 0.006 \\
\hline Intercept & 1081.322 & 1 & 108.322 & 34.100 & 0.000 \\
\hline Pretest & 670.102 & 1 & 670.102 & 21.132 & 0.000 \\
\hline Group & 50.133 & 1 & 50.133 & 1.58 & 0.213 \\
\hline $\begin{array}{l}\text { Learning Style } \\
\text { (Pre) }\end{array}$ & 115.728 & 4 & 28.932 & 0.912 & 0.461 \\
\hline $\begin{array}{l}\text { Learning Style } \\
\text { (Post) }\end{array}$ & 167.584 & 4 & 41.891 & 1.321 & 0.270 \\
\hline $\begin{array}{lr}\text { Group } & \& \\
\text { Learning } & \text { Style } \\
\text { (Pretest) }\end{array}$ & 61.584 & 3 & 20.528 & 0.647 & 0.587 \\
\hline Group & 30.083 & 1 & 30.083 & 0.949 & 0.333 \\
\hline $\begin{array}{l}\text { Learning Style } \\
\text { (Posttest) }\end{array}$ & & & & & \\
\hline $\begin{array}{cc}\text { Learning } & \text { Style } \\
\text { (pre \& } & \text { post) }\end{array}$ & 272.916 & 4 & 68.229 & 2.152 & 0.083 \\
\hline $\begin{array}{lr}\text { Group } & \& \\
\text { Learning } & \text { Style } \\
\text { (Pre \& Posttest) }\end{array}$ & 12.259 & 1 & 12.259 & 0.387 & 0.536 \\
\hline $\begin{array}{l}\text { Within Error } \\
\text { Corrected Total }\end{array}$ & $\begin{array}{l}2410.013 \\
3829.918\end{array}$ & $\begin{array}{l}76 \\
96\end{array}$ & 31.711 & & \\
\hline
\end{tabular}

i. R squared $=0.371$ (adjusted R squared $=0.205$ ) 
Table 4.3 shows the application of the three-way Analysis of Covariance which revealed that the experimental group and comparison group did not differ significantly on their achievement scores since the corresponding probabilities (0.213) associated with the F-statistic is greater than $\alpha=0.05$, which led to the acceptance of the null hypothesis. In terms of their pre and post test results, (Sensitive/Intuitive learning style), the students' achievement scores did not exhibit significant difference since their associated probabilities $(0.461 \& 0.270)$ are greater than $\alpha=0.05$. This led to the acceptance of the null hypothesis.

Table 4.4 Results of the analysis of covariance on global/sequential learners

\begin{tabular}{|c|c|c|c|c|c|}
\hline $\begin{array}{l}\text { Source of } \\
\text { Variation }\end{array}$ & Sum of Squares & $\mathrm{df}$ & Mean Square & $\mathrm{F}$ & Probability \\
\hline $\begin{array}{l}\text { Corrected } \\
\text { Model ( Bet.) }\end{array}$ & 1225.236 & 20 & 61.262 & 1.788 & 0.037 \\
\hline Intercept & 1845.241 & 1 & 1845.241 & 53.841 & 0.000 \\
\hline Pretest & 413.357 & 1 & 413.357 & 12.061 & 0.001 \\
\hline Group & 24.071 & 1 & 24.071 & 0.702 & 0.405 \\
\hline $\begin{array}{l}\text { Learning Style } \\
\text { (Pre) }\end{array}$ & 186.479 & 3 & 62.160 & 1.814 & 0.152 \\
\hline $\begin{array}{l}\text { Learning Style } \\
\text { (Post) }\end{array}$ & 156.751 & 4 & 39.188 & 1.143 & 0.343 \\
\hline $\begin{array}{lr}\text { Group } & \& \\
\text { Learning } & \text { Style } \\
\text { (Pretest) }\end{array}$ & 101.655 & 2 & 50.827 & 1.4 & 0.233 \\
\hline $\begin{array}{lr}\text { Group } & \& \\
\text { Learning } & \text { Style } \\
\text { (Posttest) }\end{array}$ & 28.949 & 2 & 14.475 & 0.422 & 0.657 \\
\hline $\begin{array}{l}\text { Learning } \\
\text { (pre \& } \quad \text { Style } \\
\text { post) }\end{array}$ & 121.829 & 5 & 24.366 & 0.711 & 0.617 \\
\hline $\begin{array}{lr}\text { Group } \quad \& \\
\text { Learning Style } \\
\text { (Pre \& Posttest) }\end{array}$ & 5.212 & 2 & 5.212 & 0.152 & 0.698 \\
\hline $\begin{array}{l}\text { Within Error } \\
\text { Corrected Total }\end{array}$ & $\begin{array}{l}2604.682 \\
3829.918\end{array}$ & $\begin{array}{l}76 \\
96\end{array}$ & 34.272 & & \\
\hline
\end{tabular}

i. R squared $=0.320$ (adjusted $\mathrm{R}$ squared $=0.141)$

Table 4.4 presents the application of the three-way Analysis of Covariance which revealed that the experimental group and comparison group did not differ significantly on their achievement scores (0.405). The F-statistic is greater than $\alpha=0.05$, which led to the acceptance of the null hypothesis. In terms of their pre and post tests (Global/ Sequential), the students' achievement scores did not exhibit significant difference since their associated probabilities $(0.152 \& 0.343)$ are greater than $\alpha=0.05$. This led to the acceptance of the null hypothesis. This means that global/sequential group of learners who are exposed to lecture discussion method performed similarly with the students taught in multimedia instruction.

\section{CONCLUSIONS}

Multiplemedia instruction and lecture method in teaching high school chemistry have similar effects on the achievement of the learners. The students in both groups learned significantly in their Chemistry subject. Learning style is not inherent in a person but it varies according to the situation. 


\section{LITERATURE CITED}

Brungardt, J.B., \& Zollman, D. A. (1996) The influence of interactive videodisk construction using real time analysis on kinematics graphing skills of high school physics students journal of research on science teaching 32, $855-869$.

Harwood, W.S. \& Mcmahon M. M. (1997). Effects of integrated video on student achievement and attitudes in high school chemistry. Journal of research in science teaching. Vol. 34, No. 6, pp. 617-631.

Internet Website. http://www.ncsu.edu/felderpublic /ILSpage.html.

Kind V. (2000). Beyond Appearances: Student's misconceptions about basic chemical ideas: A report prepared for the Royal Society of Chemistry, London: Education Division, Royal Society of Chemistry.

Kozma, R., \& Russell J. (2005) Multimedia learning in chemistry. In R.E. Mayer (Ed.), The cambridge handbook of multimedia learning, 409-428. New York: Cambridge University press.

Litzinger, M. E. \& Osif, B. (1993). Accomodating diverse learning styles. Designing instruction for electronic information sources. In what is goog instruction now? library instruction for the 90's ed. Linda Shiranto. Ann Arbor, MI: Pierian Press

Lowe R.K. (2005). Multimedia learning of meteorology. In R.E. Mayer (Ed.) The Cambridge handbook of multimedia learning. New York: Cambridge University Press. 